Early Theatre 5.1(2002)

richard f. hardin

\title{
Playhouse Calls: Folk Play D octors on the Elizabethan Stage
}

\section{The D octor of Folk Tradition}

It remains uncertain whether the English folk drama known as the mumming play coexisted with the drama of Shakespeare's age. Flourishing in the U nited Kingdom and elsewhere since the 1700s, this curious event enacts a 'hero combat' wherein a champion (often St George) boasts of his battle skill to an enemy (often a Turkish or Egyptian knight). After one opponent has killed the other, a doctor, sometimes at the urging of a young or old woman, raises the dead combatant; several unrelated characters then give brief comic speeches; the play ends with a collection of money for the players. ${ }^{1}$ W hile it is impossible to say with certainty that Elizabethans practiced this folk custom, we ought to consider that elements of the play may date back to older, if now-vanished, forms of popular entertainment. $0 \mathrm{n}$ the continent, analogues to the mumming play claim a widespread and very ancient existence. $C$ hambers writes of folk-plays representing combat, doctor, and cureexisting throughout Europe, surviving still in G reece and the Balkans in the early 1900s. ${ }^{2}$ In 1928 a folklorist reported the existence, in the French Pays Basque, of an entertainment in which a barber shaved 'the M aster G rinder' (knife-sharpener) and cut histhroat. The doctor who issummoned to bring the grinder back to life enters with a speech about his wide travels, not unlike the typical entrance lines of the mumming play doctor. ${ }^{3}$ In Russia the comic doctor, with 'a long and complex pedigreein the world of popular entertainment', appearsin C hristmas folk plays, where he resuscitates a knight killed by the C zar's champion. ${ }^{4}$ In the W estern Russian folk ritual that is the basis for Stravinsky's The Rite of Spring a doctor attempts to revive a dead virgin. In H ungary the folk-doctor appears in wedding plays, where he enters with a cure, like his mumming counterpart, at the turning point near the play's end. ${ }^{5}$ These doctors tend to share certain features with their colleague in the mumming play: they have a medicine that will bring the dead to life; they brag about their achievements, travels, or high fees; they use an often preposterous medical jargon. Several 
scholars have offered evidence that such a doctor existed in late medieval or early modern folk activities, whether in the mumming play or some other custom, and that he found his way into Elizabethan playhouses. This paper will further that line of argument.

Known evidence of the doctor in European popular or folk drama in the fifteenth century survives in several $\mathrm{G}$ erman texts. $\mathrm{H}$ ere the doctor takes on several roles, perhapschiefly in theArztspiel, or doctor play. Although this does not involve combat, it presents a learned, boastful doctor curing, or pretending to cure, peasants with a special medicine. The audience hears jokes about the peasants' stupidity, their urine samples, and the ingredients of the prescribed medicine. ${ }^{6}$ Fifteenth- and sixteenth-century scripts of G erman carnival plays (Fastnachtspiele) also survive in which comic doctors treat patients for carnival misbehavior such as overeating and sexual misconduct. ${ }^{7}$ Closer to the mumming play are a few performed texts of C hristmas plays from the $1400 \mathrm{~s}$, one of which, D as $\mathrm{N}$ eithartspil ( $\mathrm{N}$ eithart's Play), strengthens the theory that not only the doctor but something very like the mumming play existed in the later middle ages. ${ }^{8}$

In this entertainment $\mathrm{N}$ eithart, a wealthy land owner, starts a fight in which he, his knight, and a poor man kill one another. Enter the D evil to take them all to hell. When the peasant's brother calls out to heaven for aid, another peasant says, 'I know a doctor who will always heal our wounds. The doctor's name is M aster Laurein'. The doctor arrives with a bottle, proclaiming, 'I, Laurein, have a good drink. Any peasant who is wounded and sick, and drinks from this little bottle, will recover, I say this for certain'. ${ }^{9}$ The dead take the elixir and return to life; the now amicable knight and $N$ eithart go off for a drink, and the play ends with a joking speech from the Presenter. The brief description of the doctor and his stylized appearance with the cure suggest a formulaic quality about this action: the German audience of the fifteenth century apparently knew what to expect. Considering the well-known commercial, political, and theatrical associations between Germany and England in the late middle ages, it is reasonable to suppose that this familiar figure also could also have existed in England, as mountebank, a folk drama type, or even as part of an oral mumming play tradition. If so, this doctor could haveexisted among the allusive resources of the earliest modern English playwrights. In fact it appears that by 1590 in England the doctor was al ready somehow associated with St G eorge, as witness a familiar text, Book O ne of The Faerie Q ueene in the Aesculapius episode. A recently published analysis of this episode (in canto 5, stanzas 28-44) finds a mumming play analogue in the Redcross K night's 
(St G eorge's) battle with the Saracen Sansjoy. W hen Sansjoy falls, apparently dead, an 'old woman' (N ight) pleads with the ur-doctor, Aesculapius, to cure him. Asthe Saracen's mistress, D uessa resemblesthe 'king of Egypt's daughter' who does the pleading in some mummers' versions. Spenser appears to be drawing significant parallels with the mumming play or something like it, though of course the attempted resurrection fails. 10

$\mathrm{H}$ undreds of written scripts of the mumming play exist in Britain and other English-speaking countries, and though none can be dated before 1700, tantal izing hintslikethis one in Spenser suggest that Elizabethanswerefamiliar with the hero combat, doctor, and cure scene. Although the principal subject of this article is the figure of the doctor, it is worth considering whether he might have existed as we know him in the mumming play during the Elizabethan period, when doctors on stage often seem to echo his behavior.

The earliest report of this play comes from I reland in a letter apparently written in 1685:

[0 ]n our new green last evening there was presented the drollest piece of mummery I ever saw in or out of Ireland. There was St G eorge and St D ennis and St Patrick in their buffe coats and the Turk likewise and O liver Cromwell, and a D octor and an old woman - who made rare sport till Beelzebub came in with a frying pan upon his shoulder and a great flail in his hand threshing about him on friends and foes, and at last running away with the bold usurper whom he tweaked by his gilded nose - and then came a little D evil with a broom to gather up the money that was thrown to the M ummers for their sport. It is an ancient pastime they tell me of the citizens. ${ }^{11}$

The cast of characters, while a bit heavy on saints, matches the familiar figures in later such entertainments; mention of Cromwell so soon after the Protectorate indicates the temporal adaptability of folklore. But if the 1685 account is reliable - it survives in a transcription from about 1800 - it was already an 'ancient pastime' for some part, if not necessarily all, of the British I sles.

Since mummers' 'texts' belong to an oral tradition, they would have existed mainly in the memories of the actors; no early written account could be said to constitute the authentic version. Reginald Tiddy's historic collection made available a good many post-1700 versions, and the once-familiar classroom anthology of Joseph Q uincy Adams, Chi ef PreShakespearean D ramas, provided 'St George plays' from 0 xfordshire and Leicestershire for students everywhere. The 0 xfordshire play was recorded in 1853 from someone who began acting his part in 1807, following in the footsteps of his father, who 
played the part for many years before that. ${ }^{12}$ The Leicestershire text, of about the same vintage, has a 'T urkish Knight', unlike the 0 xfordshire. Both plays contain a comic doctor. A measure of how surface details may change with time is revealed in a fairly recent text of the $\mathrm{N}$ etley Abbey mumming play, where Turkish Knight has become 'T urkey Snipe' and, as in other texts, St George has become King $\mathrm{G}$ eorge. ${ }^{13}$ The hero may bear still other names in mumming plays of $\mathrm{N}$ ewfoundland, which begin early in that colony's history. ${ }^{14}$ A consistent feature, however, despite the change of names, is the doctor, with hisjokes, boasts, and cures. Even in theuntheatrical $\mathrm{N}$ ew England colonies of themid-1700s one resident remembered that a band of 'vagabonds' used to visit Boston homes on 'some holiday' with a play in which 'O ne fellow was knocked down and lay sprawling on the carpet, whereupon another called for a doctor who would revive the fallen man'.15

If the early history of the mumming play is uncertain, any explanation regarding itstheme (if any) or cultural function hasmet with skepticism. Those who suppose 'pagan' origins for the play have echoed Tiddy's early theory that it derives from a fertility ritual. ${ }^{16}$ of course, while Tiddy's research was underway, scholars habitually tied folk customs to rituals, especially those of fertility. Later, covering much of the same ground as Tiddy, E.K. Chambers laced his The English Folk Play with mentions of pagan fertility rites, thereby securing this approach in English literary and folklore study for decades to come. Aslate as the 1980s, the mumming play was defined as 'A men's seasonal ritual intended to promote fertility, expressed basically in terms of an action of revitalisation, in which the performers must be disguised to prevent recognition'.17

While at some level, given the frequency of this play in farming communities, the fertility theme is scarcely avoidable, a number of its elements seem to point in other directions. T ake the combat itself. U sually a light- and darkskinned opponent fight; either may be the victor. It seems to make no difference among the many surviving play texts whether the 'St G eorge' hero wins or dies. In the Leicestershire play the Turkish Knight wins, but the 'T urkey Snipe' loses to King George in the N etley Abbey play, as does the Black Prince('a black M oroccan dog') in the Antrobus (Yorkshire) Soulcaking play. ${ }^{18}$ The 'point' of the play or (if any) underlying ritual must tiein with the fact that invariably both opponents, however different, must live. D ifference is suggested as inevitable, perhaps essential to society. Thisfeature formerly led Thomas Pettitt to conclude that the mumming play expresses 'the interdependent relationship between agrarian classes', and certainly this view sounds 
plausible for 'D as $\mathrm{N}$ eithartspil'. ${ }^{19}$ As one folklorist has put it, folk drama 'is about consolidating the values of the community, about reproducing thelocal community and allowing it to continue'. ${ }^{20}$ In ritual's logic, reviving the dead combatant might also enable acceptance of the misfits and grotesques - those who proceed with their brief comic speeches before collecting the money: Beelzebub with his frying pan, Littlewit with his big head, and others.

It is reasonable to believe that this apparently silly entertainment or its precursor once had a serious underlying purpose, even if only to beg money. In early recorded instances the mummers entered private residences, bringing the larger community, asit were, into the home: recall the 'vagabonds' enacting combat on the carpet of respectable Boston parlors. Although nowadays mummers' performances often occur in public areas like taverns, a few, like the Antrobus play, at least as of the 1970s, makethe rounds to people's homes in the old way. O ne participant claimed that peoplein farmhouses must let the mummers in, since it is considered bad luck not to. ${ }^{21}$ Similarly, in 1930 a Kentucky mountaineers' mumming play, performed at a folklorist's request after a lapse of thirty years, opened with the announcement, 'I reckon folksall knows hit air bad luck to talk with the dumb show folks or guess who they air'.22 The supposition of bad luck supports comparing the play with a ritual, specifically one that performs its work in the community rather than, say, the farmers' fields. Victor Turner finds that such 'obligation', as opposed to 'optionality' (typical, eg, of modern mumming plays, in which theactorsmust ask permission to enter the house), signifies true ritual 'liminality', the participatory stage in 'the social process whereby groups become adjusted to internal changes'. ${ }^{23}$

Thedecline of orality in the culture would explain the volume of mumming play texts existing after 1700, while the far greater likelihood of memorial preservation before that date would have made written scripts unnecessary. Some of the most persuasive evidence for a pre-1600 play has turned up in literary texts during the century before Shakespeare, beginning with the moralities and pageants of the 1400s. In this respect Peter $\mathrm{H}$ appé notes the apparent use of masks in recorded St G eorge plays; he also finds traces of the 'cure' (the revival by the doctor) in $M$ ankind, a connection also made in earlier scholarship. In Wit and Science W it is killed and then cured, while comic doctors appear in the Croxton Play of the Sacrament and several other earlier T udor plays. ${ }^{24}$ E.K. C hambers cites, as evidence for the mumming play's early existence, the figure of the doctor who cures $C$ onstantine in the Cornish play of Saint M eriasek (1504). H e also finds a London procession of M arch 1553 
with a scene in which Jake-of-lent's wife begged his physician to save his life, 'and he shuld [give him] a thowsand li. for ys labur'. ${ }^{25}$

\section{A D octor in the H ouse}

Later in the sixteenth century the doctor finds his way into more familiar plays. O ne folklorist has linked Jonson's Volpone playing mountebank to the folk-play doctor in hislines boasting of his travels and cures. ${ }^{26}$ Another scholar proposes that the mumming 'cure' scene prompted Theseus's remark in A $M$ idsummer N ight's D ream concerning the dead Pyramus: ' $W$ ith the help of a surgeon he might yet recover' (5. 1. 297). Sincethe Pyramus-T hisbe play jokes about lower-class attempts at high theatre, a fair reading of this line is that Theseus expects the mechanicals to produce something as trite and unsophisticated as the stage doctor's cure. The mumming play also seems to inform Thomas Randolph's less familiar play Aristippus (1626), as Aristippus, killed by a brewer named W ildman, is resurrected by 'Signior M edico del Campo'. 27

The elements of doctor and cure exist or survive in other Renaissance plays, including at least a dozen by Shakespeare. When Francois Laroque praises Shakespeare as 'a genius at making dramatic use of all the flotsam and jetsum of myth and the vestiges of folklore', herepeats a view expressed by J anet Spens as early as 1916, though sheand other scholars venturing on thisline of inquiry have seldom examined Shakespeare's work for traces of the folk play doctor. ${ }^{28}$ O ne such trace is the figure of the 'fifth-act physician', so designated, though without reference to the mumming play, in a study by Philip Kolin. This character usually shows up to attempt a cure late in a play (sometimes in Act 4) - in other words, at a point corresponding to the doctor's entry in the mumming play. Kolin's examples in the plays of Shakespeare's contemporaries include the physician to the hyperbolic 'T urkish Knight'-type T amburlaine, victim of his own inner choler. The doctor in M arlowe's play can only furnish a diagnosis, no cure. Themad Ferdinand's doctor, entering latein TheD uchess of $\mathrm{M}$ alfi belongs to a Jacobean fraternity of soul-doctors that also includes Alibius in The Changeling. ${ }^{29}$

Before turning to the doctor in Shakespeare, I wish to mention some hitherto unobserved instances from other playwrights of the time. The presence of these stage doctors, added to those that other scholars have discussed, suggests that during the sixteenth century this figurehad become a convention - I suggest by way of folk entertainment. The fifth-act doctor's function sufficiently resemblesthat of hiscolleaguein the folk play to support thetheory 
that playwrights consciously imported the character from the mumming play, or from an entertainment strikingly like it.

In Thomas D ekker's The H onest W hore, Part O ne (1602?), showing influence from Romeo and Juliet, Doctor Benedict works as something of an intriguer, as do a number of these doctors. In thefirst act hehas al ready drugged the $D$ uke of M ilan's daughter at the Duke's request to prevent her marrying $\mathrm{H}$ ipolito, son to the Duke's enemy. By act 4 the D uke solicits the doctor to poison $\mathrm{H}$ ipolito too; but then he makes the serious error of refusing to pay the doctor's fee as promised. The prescient doctor - or is he just angry over his fee? - goes at once to $\mathrm{H}$ ipolito, tells him his beloved is alive, and tells the lady that, contrary to what she has heard, so is $\mathrm{H}$ ipolito. In act $5 \mathrm{~F}$ riar Anselmo, disclosing the news of these revivals, urges that the marriage bring peace to the two hostile families. The doctor's cure, then, extends not just to the lovers but to the central conflict in the world of the play, resolving the bitterness between two noble families. This movement from cure of body to cure of community appears a common feature in most of the plays under discussion, especially the comedies and tragicomedies.

From about thesametime, G eorgeC hapman'sT he Gentleman U sher (1604) concludes with a similar medical miracle when the heroine $M$ argaret, despondent because she must marry $M$ ister $W$ rong and lose $M$ ister Right, has disfigured her face with a corrosive ointment. For Chapman's audience, of course, a life without marriage amounted to death for a woman. Fortunately D octor Benevenius brings life out of this death by administering an elixir and a 'recureful mask' (5.4.132) that will restore the desperate woman to her beloved, face intact. ${ }^{30}$ D uke Alphonso handsomely compensates the doctor 'both with gold and honor' (line 145). Cured both in spirit and body, M argaret anticipates a renewal of her society that will comewith a providential marriage. Both D ekker's and Chapman's plays end in the way of a thousand other comedies, with marriageand cel ebration; my point is that in both a doctor acts to enable the marriage by overcoming death. The Gentleman $U$ sher, incidentally, incorporates the typical Elizabethan conglomeration of disparate theatrical traditions: Sarpego reenacts his schoolboy role as a Plautine parasite; act 1 scene 2 contains a court masque of an enchanter; then come 'rude sports' as broom-man and -maid and rush-man and -maid enter, heralded by the centuries-old call to 'make room': 'A hall, a hall; whist, still, be mum, / For now with silver song they come' (2.1.225-6). H ow many of the spectators, back in their home villages and manor houses, would have heard the same call to be 'mum' during a folk play featuring a doctor? 
Benevenius was not $C$ hapman'sfirst stage doctor. In the comic masterpiece, All Fools (1599), the surgeon Pock performs the physician's role in the climax of the subplot dealing with the absurdly jealous Cornelio. That episode, in 3.1.334-423, begins when Cornelio bursts on the scene responding to taunts from the braggart D ariotto, who hints that he has slept with Cornelio's wife. Each combatant has only the briefest challenge before Cornelio wounds $D$ ariotto. Someone sends for a surgeon, Pock, who introduces some bawdy humor into the moment, with puns on his name (Pock-pox): this name 'has made many doctors'; it is 'of an ancient descent'; the pedigree comes ' $O$ ut of France'. Pock also enjoys using the kind of medical jargon sometimes spoken by mumming doctors: 'I'll make your head as sound as a bell, I will bring it to suppuration, and after I will make it coagulate and grow to a perfect cicatrice'. This will cost the usual exorbitant doctor's fee - in this case, forty crowns (inevitably, a pun on pox and crowns). ${ }^{31} \mathrm{D}$ ariotto typifies the predatoriness toward women that permeates his society, so although Pock appears only in this scene, his 'cure' can beseen as starting the resolution of the play. $\mathrm{N}$ o revival of the dead occurs, but the 'cured' D ariotto will next appear in the final scene, exposed as part of the stage-full of 'fools' who have gotten their comeuppance.

M iddleton and Rowley'sA Fair Q uarrel (1615?) invites particular attention because its cast includes both a physician and a surgeon. Since the former is a dishonest man who takes advantage of J ane's embarrassed condition to force himself on her, one point of the doubling up is that no elixir can cure this community; a more radical cutting and suturing are required. Latein the play, when the colonel appears to have been mortally wounded in his duel with the captain, the surgeon enters with a mouthful of delightful jargon of the kind, though not the amplitude, spoken by Chapman's Pock: chilis, cava vena, oesophag, syncope, tumefaction, calaphena, opponax; 'the wound, I can assure you, inclines to paralism, and I find his body cacochymic' (4.2.27-27).32 W hen, a few scenes later, the colonel appears onstage alive, a miracle seems to have happened not unlike the folk doctor's restorations. The surgeon enjoys the privilege of announcing his success in his usual grandiose terms (5.1.380) before receiving his fee from a surprised and grateful captain. Partly as a result of the surgeon's work the captain's cousin will now marry the colonel's kinsman, one of several events bringing a restored amicability to the two families torn by the duel. If recognized as a mumming play figure, the surgeon al so casts a satiric light on the duel in this anti-dueling play, reducing it from an affair of noblesse to the crude level of the mumming play brawlers. 


\section{Shakespearean Physic}

The meaning of the folk play's combat, doctor, and cure requires a theory adequate to the play's emphasis on revival and reconciliation - themes that Spenser and the dramatists just considered appear to have recognized in appropriating the doctor with his cure. Spenser's Aesculapius episode in The F aerie $Q$ ueene touches the heart of the mumming play symbolism, reinforced by wordplay throughout Book 1 on H oliness-W holeness. Because St G eorge enacts the social drama of the English church and people on the path to holiness, the reconciliation lies with $\mathrm{G}$ od rather than with human combatants. The cure, from C hrist as the true doctor of souls, is withheld in the Legend of $\mathrm{H}$ oliness until the hero risesfrom near death in the dragon fight, with the water from the holy well and the balm flowing from the tree (canto 11), allusions to the rituals of baptism and the eucharist. In The G entleman $U$ sher, The H onest W hore, and A F air Q uarrel the cure or revival achieves a more earthly reconciliation between warring families just as the former combatants leave the stage arm in arm in the mumming play. As earlier noted, both Renwick and Pettitt have proposed that at the heart of the mumming play lies a symbolism, not of fertility, as in the Tiddy-Chambers tradition, but of the interdependence of self and other in the community. Such centering in the community, along with the formulaic structure, would support viewing this play asin somesenseritual, distasteful as that word is to many current scholars of folk drama.

Acts of conflict and reconciliation call for a theory resembling Victor T urner's well known ideas on ritual as a community activity aimed at restoring balance in the social order. ${ }^{33} \mathrm{M}$ uch of what T urner says in his From Ritual to Theatre could easily apply to the ritual traces or 'liminoid' features of the folk play. In a pure ritual process likethe 'shaman's journey', 'theinitiand is broken into pieces then put together again as a being bridging visible and invisible worlds'. M ost famously, T urner defined ritual as a process of transformation whereby an authentic reordering comes about in a community. As it evolves in history, ritual tends especially to produce, he says, performative genres like stage drama, mumming, $\mathrm{H}$ alloween masking, and fiestas - all 'liminoid' activities. ${ }^{34}$ Certain aspects of mumming indeed preserve true liminal, ritual characteristics, such as the sense of danger and obligation. Recall the Kentucky mountaineer's warning that bad luck falls to anyone trying to identify the actors in the play. M ight it not be that in healing the social breaks (between classes, sexes, families), ritual and some of its theatrical liminoid derivatives seek to heal the social and familial fractures represented in the dramas of Lear 
and Pericles? O Id D r Ball in the O xfordshireSt G eorge play claims to cure 'All pains within and pains without'. ${ }^{35}$

Of course, Aristotle's idea of catharsis in drama offers an alternative explanation for the presence of physicians in Elizabethan plays. Furthermore, Shakespeare himself apparently shared a widespread belief in the therapeutic value of art, for if he speaks through his narrator in Lucrece, the tragic heroine finds ease from suffering, if not a cure, in contemplating the painting of T roy: 'It easeth some, though none it ever cured, / T o think their dolour others have endured' (1581-82). Yet the entry of his fifth-act physicians with their medicines fits the pattern observed in other plays of his time. Shakespeare's stage-doctors, both early and late, include inept D octor Pinch and the pharmacist abbessin Comedy of E rrors $(4.4,5.1)$, the apothecary and Friar Laurence in Romeo and Juliet, the doctors in King Lear (4.7) and M acbeth $(5.1,5.3)$, the medically adept $M$ arina and C erimon in Pericles $(3.2,5.1)$, D octor Cornelius in Cymbeline (5.5), the doctor who cures the jailer's daughter in T wo N oble Kinsmen, and for good measure D octor Butts, the King's physician in H enry VIII (5.2). T o thesehealers, add theslightly displaced physician-typesin several plays, and the arguable cases of some pre-fifth-act doctors like Caius in M erry Wives of W indsor and H elena in All's W ell That EndsW ell. The late-appearing doctors in Shakespeare especially imply that some activity similar to the mumming play cure existed in the late $1500 \mathrm{~s}$. T heir speeches and cures often bear a marked resemblance to those of their later folk-play counterparts.

Shakespeare's double doctors, Pinch and the abbess, appear in a plot centered on doubles. Although the stage directions call Pinch a schoolmaster, when Adriana brings him on stage (4.4.50), she calls him 'D octor Pinch' and his first gesture is to feel his 'patient's' pulse. $\mathrm{H}$ is failed exorcism yields, in the next scene, to the Abbess, with her physic based more wisely on the reciprocal needs of body and soul. In a speech laced with the jargon of medicine so exaggerated by the folk doctors, she finds her patient a victim of bad digestion leading to choler, but curable by 'wholesome syrups, drugs, and holy prayers' $(5.1 .74,104)$. If the ensuing resurrections (mother, father, twins, each believed dead by the other) do not exactly depend on a magic potion, they serve as a climax akin to that of thefolk play, reuniting theinterdependent self and other, the living and the dead. This doctoring also sets up the comic ending and resolves the discord in the larger community (money misunderstandings, scandal ous behavior) much as weddings and legal trials do in other comedies.

$T$ races of the curescene occur in other early plays: the lovers in M idsummer $N$ ight's $D$ ream receive a restorative potion; in Romeo and J uliet Friar Laurence's 
medicine fails, preventing the desired union. In view of the likelihood that the actor who played the Friar doubled with the one who played the A pothecary later in the play, we can read both characters as contributing to the multiple ironies of failed 'cures' and frustrated revivings. ${ }^{36} \mathrm{M}$ acbeth, known for its varied uses of earlier English dramatic resources, ${ }^{37}$ contains both $C$ hristian allusions (the ironic Last Supper and the washing of hands) and folklore (witches, bearbaiting). The doctor of folk plays could comfortably enter practice with $M$ acbeth's doctor, who cannot minister to a mind diseased, and with the English doctor in 4.3, attending the king-physician who cures the king's evil. King Edward, of course, healing by divine right ('H ow he solicits $\mathrm{H}$ eaven, I $H$ imself best knows' 4.3.150), would have appealed to James I's insatiable religiosity. When M acbeth's doctor cannot treat his queen, he confirms the spiritual morbidity afflicting $M$ acbeth's kingship. ' $M$ ore needs she the divine than the physician', says that doctor of his royal patient (5.1.82). The mumming play doctor often puts a comically high fee on his cure, but M acbeth's doctor departs wishing to put miles between himself and D unsinane: 'Profit again should hardly draw me here' (5.3.62). The theme of community wholeness, too, so integral to the folk play and surviving in the plays of D ekker and C hapman, resonates in M acbeth's lines to the doctor:

If thou couldst, doctor, cast

The water of my land, find her disease,

And purge it to a sound and pristine health,

I would applaud thee to the very echo

That should applaud again. (5.3.50-4)

The 'sweet oblivious antidote' $M$ acbeth seeks (5.3.43) - a drug like the one that cures the dead combatant in the folk play - appears ironic here since it should return the dead from oblivion, just as F riar L aurence's drug should have done. ${ }^{38}$ In both cases the failure of theanticipated cureadds power to theplay's tragic reversal.

The varied elements of traditional drama in $M$ acbeth show the playwright sharing with other Elizabethan dramatists a skill in using 'a subversive tradition, taken from the people, which could be used to express sophisticated criticism and dissent'. ${ }^{39} \mathrm{D}$ escribing this tradition, SandraBillington refershere to the mystery and morality dramas; folk drama also belongs with these resources(though along with them it is sometimes 'subversive' sometimes not). Soul-dead M acbeth, the T urk-like tyrant, proves ineligible for resuscitation. 
By way of contrast, a sympathetic doctor, using the elixir of music, attends the quarto King Lear's revival and repentance (4.7). ${ }^{40}$ In Pericles, too, M arina's 'sacred physic' (5.1.73) requires music to cure the wandering king. The princess must restore both spiritual and emotional life to a soul near dead, not with M acbeth's self-inflicted evils, but with those of Fortune's battering engine. D uring a scene of great solemnity Shakespeare doubles the fifth-act cure with another restoration, of Thaisa at E phesus. As the king is restored to his land, woman returns ('Flesh of thy flesh') to her mate. Cerimon, student of physic (3.2.32), had earlier brought her corpse to life with, again, the aid of music $(3.2 .89,91)$.

In the last plays such supernatural physic belongs to Paulina and Prospero as well. N or should we forget the doctor who, in The T wo N oble Kinsmen at theend of act 4, curesthejailer's daughter of her lovefor Palamon, so hopelessly above her class. Folk dancing, especially Morris dancing, occupies several characters in this play, so the doctor serves as another instance of this folk-art register. W alter C ohen remindsus that 'T heD octor who prescribes[thejailer's daughter's] cureearlier ministered to King L ear and rather more unsuccesffully to Lady M acbeth'. ${ }^{41}$ C ornelius in Cymbelinefurnishes an example of a fifth-act doctor who more closely fits the folk-play doctor's role. To Cornelius's news that the queen has died, $C$ ymbeline responds in tones of patience that contrast with M acbeth's despair:

Who worse than a physician

W ould this report become? But I consider

By med'cine life may be prolong'd, yet death

W ill seize the doctor too. (5.5.27-30)

In a romance so rich in folk motifs, the lines cast a pall of reality, as the doctor's arrival seems to portend death, not cure. But the portent then turns back on itself when Cornelius proves after all to be the reviving doctor that the audience might haveexpected. Corneliushassubstituted asleeping potion for thepoison thequeen would have given Imogen. Yet just before he reveals the switch, Posthumus, convinced that I mogen has died, unaware that shestands before him disguised as a page, knocks her down because she has dared to interrupt his lamentation:

Posthumus. Shall's have a play of this? Thou scornful page

There lie thy part.

Pisanio. 0 , gentlemen, help 
M ine and your mistress! 0 , my Lord Posthumus!

You ne'er killed Imogen till now. H elp! help!

M ine honour'd lady! (5.5.228-32)

The lines of Posthumus and Pisanio replicate the standard pattern of the folk play: one character knocks another down; someone cries out that the fallen character is dead and calls for help. A short time later the doctor revives the victim - here with the information that resolves both the lovers' and Pisanio's misunderstandings. Posthumus's 'Shall's have a play of this?' may even bea sly clue from a playwright who enjoys embedding plays in his plays. Arewe about to see a mumming play? The court does indeed see a combat and revival, followed by a union not just of man and woman but of the warring nations to which each belongs. ${ }^{42} \mathrm{~T}$ he problematic end of the political plot, with Cymbeline agreeing to pay the Roman tribute, does not resolve itself easily in representational terms, but if we think of this play as akin to folk drama, it requires that the boastful, opposed nations leave the stage arm in arm.

Along with other dramatists of his time, Shakespeareemploys theessentially comic fifth-act physician (again to use Philip Kolin's convenient tag) in comedy, to confirm the comic ending, or in tragedy, to undercut any expectation of a comic resolution. Thefrequency of thesedoctors, somecomic, some serious, who bring the dead to life and otherwise help bring reconciliation into the play's world, supports the view, shared by many since Chambers, that this figure was familiar in some kind of popular entertainment, most likely a play not unlike the mumming play extant since the early 1700 s. At the very least, if the doctor had yet to join the mummers, he was a standard comic type in popular entertainment, a sort of free radical who eventually attached himself to the mumming play. In Shakespeare and other dramatists, the evocation of the folk play, or at least the doctor figure, derives from a wholefabric of allusive potential. A fifth-act doctor, a dead combatant, and a resurrection constitute a signal to an audience, from a popular source, comparable to the display of couples chasing through the woods on M idsummer Eve. Although the argument of this article is not immune to the charge of question-begging (using the presence of folk-play elements on the stageto argueboth the existence and influence of that play), the presence of certain details in Elizabethan drama cries out for recognition. Consideration of these details offers the delight of widening the boundaries of the possible in interpretation. The details themselves may survive not only as terms of a playwright-to-audience code, but as the tacitly acknowledged trace of a ritual of social healing. 
N otes

1 Among scholars agreeing that the mumming play had an earlier existence are Alan Brody, The English M ummers and Their Plays: Traces of Ancient M ystery (Philadelphia, 1970); E.C. Cawte et al, English Ritual D rama: A Geographic Index, Publications of theFolklore Soc., 127 (London, 1967); Alex H elm, The English M ummers' Play. Folklore Society M istletoe Series, 14. (W oodbridge, Suffolk, 1981); GlynneW ickham, The M edieval Theatre, 3rd ed (C ambridge, 1987). I should state that the British mumming play is a site of significant debatenowadays: seeEddieC ass, M ichael Preston and Paul Smith, T heE nglish M umming Play: An Introductory Bibliography, Folk Lore Society Books, Bibliographies N o. 2 (London, 2000). Steve Tillis, Rethinking Folk D rama (W estport CT, 1999) thinks scholarship has been excessively concerned with origins of the play (179), and other current scholars most involved with the subject agree (eg, Eddie C ass and M ichael Preston, whose preferred label, 'mumming play', I use, and whose particular skepticism about the ritual origins of the play knows no bounds). On the web, see the invaluable site of the Traditional $D$ rama Research Group centered at the U niversity of Sheffield, «www.shef. ac.uk/uni/projects/tdrg>. François Laroque, Shakespeare'sF estiveW orld (C ambridge, 1991), assumes too confidently the play's existence during the 1500s $(50-5,83,124)$. I wish to emphasize that I deal chiefly with the doctor. REED volumes yield no evidence of this figure, but in the 1500s the D ublin T ailors' G uild provided the St G eorge's $D$ ay pageant with costumes for 'the Emperor, with two D octors, and the Empress, with two knights and two maydens'. In 1552 a charge for 'paynting the emperors hed' raises the question whether the doctors may have ministered to a beheaded emperor. See John J. W ebb, The Guilds of D ublin (D ublin, 1929), 90-1.

2 E.K. Chambers, The English Folk Play (O xford, 1933), 198-229.

3 Violet Alford, 'T he Basque M asquerade', Folklore 39 (1928), 80.

4 Elizabeth A. W arner, 'The Q uack Doctor in the Russian Folk and Popular Theatre', Folklore 93 (1982), 166.

5 Zoltán U jváry, 'D er Arzt-Zauberer in den dramatischen Spielen', Ö sterreichis ches Zeitschrift für Volkskunde 41 (1987): 'D as Auftreten des Arztes und seine Rolle bedeuten im Ablauf der Ereignisse so einer Szene einen Wendenpunkt; er treibt die $\mathrm{H}$ andlung voran, ein anderes $\mathrm{M}$ al bildet sein W irken den Abschluss des Spiels' (127). The doctor ushers in the 'Wendenpunkt' (turning point) of the play in a number of the English plays I discuss. 
6 Carl I. H ammer, Jr., 'T he D octor in the Late M edieval "Arztspiel"', German Life and Letters 24 (1971), 244-56.

7 M artin W. Walsh, 'Q uacks, Empirics, Spiritual Physicians: The D ramatic function of the M edicus in $15^{\text {th }}$ and $16^{\text {th }}$ Century Fastnachtspiele', Fifteenth Century Studies 8 (1983), 239-74.

8 Adelbert Keller (ed), Fastnachtspiele aus dem fünfzehnten Jahrhundert (1853; rpt. D armstadt, 1965), I, 197. This is K eller no. 21, a source mentioned by Thomas Pettitt, 'English Folk D rama and theE arly G erman Fastnachtspiele', Renaissance D rama 13 (1982), 1-34, who notes similar instances of combat and doctor in nos. 57 and 66.

9 Ich weiss ein arzt, derselbig sol

Unser wunden imer hailen rein

Der arzt haisst maister Laurein.

Ich Laurein hab ein guts getrank.

Welcher paur is wunt und krank

Und trinkt aus dem fleschlein, im wirt pas.

Fur ein warheit sagich das.

I wish to thank my colleague Frank Baron for help with the German.

10 Richard F. H ardin, 'Spenser's A esculapius and the English M ummers' Play', Spenser Studies 15 (2001), 251-3.

11 Q uoted in $\mathrm{H} \mathrm{elm}$ (above, $\mathrm{n} \mathrm{1),} \mathrm{7.} \mathrm{A} \mathrm{problem} \mathrm{is} \mathrm{that} \mathrm{the} 1685$ account was transcribed by one Thomas C roker in a manuscript of 1800 and does not itself survive. There is no evident reason not to take the copyist at his word, but see T om Pettitt, 'C ork R evisited: A Reconsideration of some Early Records of the M ummers' Plays', Traditional D rama Studies 3 (1994), 15-30.

12 R.J.E. Tiddy, The M ummers' Play (Oxford, 1923); J.Q. Adams (ed), Chief PreShakespearean D ramas (Boston, 1934), 353-6. Tiddy wrote this book beforehis 1916 death in the war. H eapparently lacked the detailed knowledge of early English and European drama underlying the work of Chambers and others.

13 Brody, The English M ummers and their Plays, 31-6.

14 See H erbert $\mathrm{H}$ alpert and G.M. Story (ed), Christmas M umming in N ewfoundland, 2nd ed (T oronto, 1990).

$15 \mathrm{H}$ alpert and Story, Christmas M ummery, 52.

$16 \mathrm{H}$ alpert and Story, Christmas M ummery, 70, 90.

$17 \mathrm{H}$ elm, The English M ummers' Play, 6; see also Laroque, Shakespeare's Festive W orld, 54. 
18 On the Soulcaking play see A.E. G reen, 'Popular D rama and the M ummers' Play', in D avid Bradby et al (ed), Performance and Politics in Popular D rama (C ambridge, 1980), 139-66. Tillis notes that the St George figure 'dies' in as many as a third of the known texts (182).

19 Thomas Pettitt, 'Early English T raditional D rama: Approaches and Perspectives', RO RD 25 (1982), 10. Thisremains, in my view, themost valuablestarting point for a literary scholar's research on the English mumming play. Pettitt himself seems to have shifted his views on the subject somewhat (see above, $\mathrm{n}$ $11)$.

20 Ruarí Ó C aomhanach, 'I rish Folk D rama', TheM agazinefor T raditional M usic (Article M T 010), 16 D ecember 1998, «www.mustrad.org.uk/articles>. Tillis (see above, $n 1$ ), also very recently, urges his and others' view that the theme of the mumming play is 'a sense of community' (193).

21 Green, 'Popular D rama', 158.

22 Q uoted in J an $\mathrm{H}$ arold Brunvand, TheStudy of American F olklore, 2nd ed ( $\mathrm{N}$ ew York, 1978), 268, from M arie Campbell, 'Survivals of O Id Folk D rama', JAF 51 (1938), 10-24.

23 Victor T urner, From Ritual to Theatre: The H uman Seriousness of Play (N ew York, 1982), 42, 21.

24 Peter H appé, 'T heV iceand theFolk-D rama', Folklore 75 (1964), 161-93. 0 n $M$ ankind see $W$ alter $K$. Smart, 'M ankind and the M umming Plays', M LN 32 (1917), 21-5, which focuses on lines 426-68 of the play. Smart cites and clearly follows the views of E.K. Chambers in The M edieval Stage (London, 1903).

25 Chambers, The English Folk-Play, 169, 155.

26 Brody, TheEnglish M ummers and their Plays, 57.

27 Kenneth Friedenreich, 'Shakespeare, $M$ arlowe, and the $M$ ummers', American $N$ otes and Queries 20 (1982), 98-9; M artin Walsh, 'Thomas Randolph's Aristippus and the English M ummers' Play', Folklore 84 (1973), 157-9. For yet another, more involved comparison between an Elizabethan play and this folk play, see Roger deV. Renwick, 'T he M ummers' Play and The O Id Wives' Tale', JAF 94 (1981), 433-55.

28 Laroque, Shakespeare's Festive World, 191. Efforts toward anthropological study of the literature of thisperiod include Robert W eimann, Shakespeareand the Popular T radition in the Theater (Baltimore,1978) and François Laroque (above, $n 1$ ). Laroque discusses the play sparingly. D eserving more recognition as an early anthropological critic, J an et Spens, An Essay on Shakespeare'sR elation 
to Tradition (Oxford, 1916), 35-52, observes some traces of folk plays in Shakespeare, though she does not mention the doctor.

29 Philip C. Kolin, The Elizabethan Stage D octor as a D ramatic Convention. Salzburg Studies in English Literature(Salzburg, 1975), 30-1, 121. T his 1973 $\mathrm{N}$ orthwestern U niversity dissertation provides an ample inventory of stage doctors, but there is no attempt to link them with the Mummers' doctor, briefly mentioned on 8-9.

30 Chapman, The G entleman U sher, John H azel Smith (ed), Regents Renaissance D rama (Lincoln NE, 1970).

31 Chapman, All Fools, Frank M anley (ed), Regents RenaissanceD rama (Lincoln $\mathrm{NE}, 1968), 3.1 .376,379,381,411-13$.

32 Thomas M iddleton and W illiam Rowley, A Fair Q uarrel, R.V. H oldsworth (ed), N ew M ermaids (London, 1974).

33 T urner's theories evolved over three decades, from his early field work with $\mathrm{N}$ dembu ritual to the fruitful study of drama and ritual with Richard Schechner in one of his last books, From Ritual to Theatre (see above, $n$ 23). Rituals assist the community in dealing with change. D uring ritual, participants are in a state of liminality ('thresholdness'), a condition that takes them out of the prevailing social structures into 'communitas', where social differences are temporarily suspended, leading to a renewal of the group's or congregation's sense of mutual dependency. 'Communitastends to beinclusive- somemight call it "generous" - social structure tends to be exclusive, even snobbish, relishing the distinction between we/they and in-group/out-group, higher/lower, betters/menials' (51). M odern civilization creates 'liminoid' activities (eg, theatre, sports, political rallies), in which some traits and functions of liminality survive.

34 T urner, From Ritual to Theatre, 79, 42.

35 Adams, Chi ef PreShakespearean D ramas, 354.

36 D ominic G race, 'Romeo and the A pothecary', Early Theatre 1 (1998), 27-38, considers the Friar-Apothecary doubling. Caroline di M iceli, 'Sickness and Physic in Some Plays by M iddleton and W ebster', C ahiers Élisabéthains 26 (1984), 41-78, notes the identical functions of doctor and apothecary in Jacobean tragedies.

37 See Howard Felperin, Shakespearean Representation (Princeton, 1977), 118-44. Technically the cycle plays that so invest $M$ acbeth, having corporate sponsorship and doctrinally informed playwrights, arenot folk drama; but they include many elements that must have originated in folk entertainment, such 
as the quarreling couple ( $\mathrm{N}$ oah and his wife) and the ranting jealous husband (St J oseph).

38 When Simon Forman ends his famous note on the play with the sentence, 'And the doctor noted her [Lady M acbeth's] words', his use of the definite article could imply that 'the doctor' was for him a familiar character.

39 Sandra Billington, M ock Kings in M edieval Society and Renaissance D rama (O xford,1991), 254.

40 In the folio version of Lear the doctor and the music therapy vanish, perhaps because the author had second thoughts about 'the way the D octor, in the first version, took charge of a situation which is surely for Cordelia to handle'. M . M. M ahood, Bit Partsin Shakespeare's Plays (C ambridge, 1992), 167.

41 Cohen (intro), T he T wo N oble Kinsmen, in T he N orton Shakespeare, Stephen G reenblatt (ed), (N ew York, 1997), 3197.

42 N orthrop Frye, A N atural Perspective (San D iego and N ew York, 1965), says a'healer' or 'preserver of life' in theromancesisassociated with 'natural society', citing Cerimon and, in this play, Pisanio, having 'an association by proxy with the medical profession in the drug he gives to Imogen' (144). Knowledge of the folk doctor removes the need for a proxy. W illiam Barry Thorne, 'Cymbeline: "Lopp'd Branches" and the Concept of Regeneration', SQ 20 (1969): 143-59, in a general study of folk motifs in this play, links C loten's fate with the Sword Dance folk entertainment, in which the Fool is beheaded and revived by the doctor (155). 